\title{
Odontophrynus barrioi, a New Species of Anuran from Argentina
}

\author{
J. M. CEI, ${ }^{1,2}$ I. R. G. RUIZ, ${ }^{3}$ AND W. BEÇAK ${ }^{3}$ \\ 'Universidad Nacional de Rio Cuarto, Dpto. Ciencias Naturales, Cordoba, Argentina \\ ${ }^{2}$ Rancho Somuncura, Rua Fausto de Figueiredo Birre, 2750 Cascais, Portugal \\ ${ }^{3}$ Serviço de Genética, Instituto Butantan, Sâo Paulo, Brasil (address reprint request to Beçak)
}

\begin{abstract}
A new species of Odontophrynus from $2200 \mathrm{~m}$ altitude in the Sierra de Famatina, Argentina, is described. Morphological as well as cytogenetic features differentiate the new species, $O$. barrioi, from the populations of the $O$. occidentalis group.
\end{abstract}

The genus Odontophrynus is widespread in several regions of southern and eastern South America. In arid and subarid territories of western Argentina, Odontophrynus occidentalis (Berg, 1898) is predominant, sympatric with $O$. americanus in the eastern pampean boundaries. The range of the group extends in subandean areas along the Cordilleran Mountains, at 500 to $2000 \mathrm{~m}$ of altitude in Catamarca and the La Rioja Mountains in the north. Southwards it reaches northern Patagonia in Rio Negro and Neuquén Provinces, but marginal populations are also found eastwards in the pampean reliefs of the Sierras of Cordoba and San Luis and on the sandy Atlantic coasts of Buenos Aires Province (Savage and Cei, 1965; Barrio, 1964; Cei, 1980a) (Fig. 1).

Having in mind the characteristic cytogenetic features of $O$. americanus whose diploid-tetraploid populations were described by Beçak et al. (1966, 1970), a comparative populational study on O. occidentalis was carried out. During this study polyploid populations of $O$. occidentalis were not detected. However, significant karyotypic differences in heterochromatin patterns were found between an isolated population from the extra-Andean Famatina massif in La Rioja Province, and several other populations ranging from Mendoza to the southernmost localities in the species distribution (Ruiz et al., in press). Besides the karyotypic differences, these populations are different in several morphological and biological characteristics.

The isolated population from the La Rioja Mountains lies in a geographical area characterized by striking endemisms (Cei, 1980b), and is described as a new form of the genus. Holotype and paratypes are deposited in the Zoological Museum of the University of São Paulo (MZUSP).

\section{Odontophrynus barrioi sp. nov.}

(Fig. 2)

Holotype.-MZUSP 57635. An adult male, from Aguadita springs, $2200 \mathrm{~m}$, $30 \mathrm{~km}$ north of the village of Famatina, Sierra de Famatina, La Rioja Province, Argentina, collected on 17 November 1978 by J. M. Cei.

Paratypes.-MZUSP 57635-57638, two adult males; 57636-57639, two adult females; 57640-57647; eight juvenile specimens; all the same data as the holotype.

Definition.-A stout Odontophrynus of the occidentalis group, characterized by small, high head; nostril very near tip of snout; diameter of eye about equal to its distance from nostril; interorbital distance about one-half width of upper eyelid; no well defined parotoid glands; irregularly arranged rounded glandular warts; lateral fringes poorly developed on fingers; metatarsal tubercle shovellike, moderately developed; short fore- 


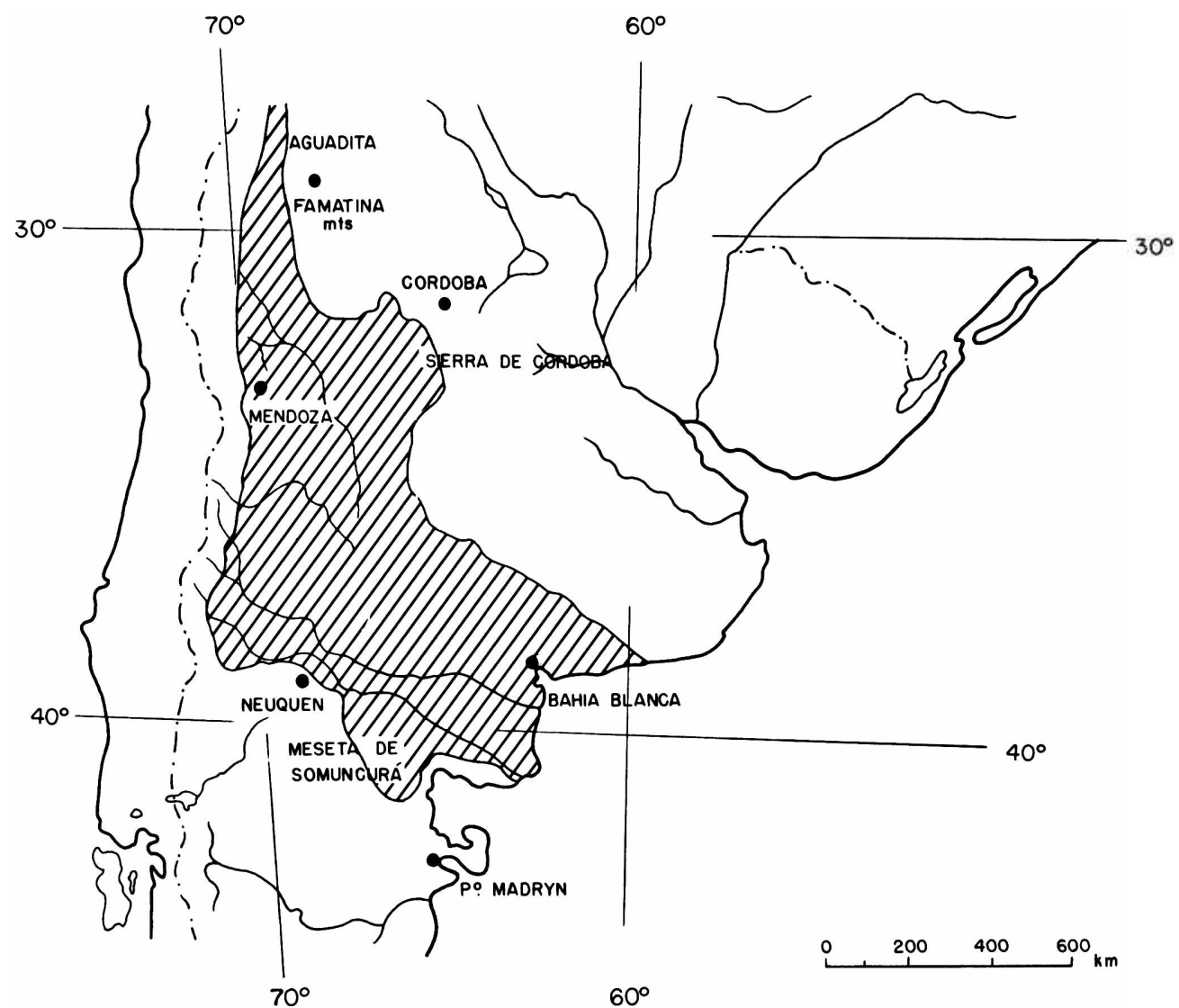

FIG. 1. Tentative distribution of the Odontophrynus occidentalis group in western and central Argentina (hatched area). Type-locality of O. barrioi in Sierra de Famatina, La Rioja Province (black area).

limb and hind limb; tibia equal to femur; vertebral light stripe absent.

Description of the Holotype.-Body chubby, with stout forelimbs and hind limbs. Head small, high, wider than long, one-fourth body length. Snout short and rounded, sharply truncate in profile. Nostril lateral, nearer tip of snout than eye. Diameter of eye about equal to distance from nostril to anterior corner of eye. Interorbital distance equal to distance between nostrils, and about one-half width of upper eyelid. Canthus rostralis bluntly rounded. $\mathrm{Pu}$ pil elliptical; tympanum concealed; two flattened glandular warts between eye and tympanum; an enlarged bulky gland on upper eyelid. Tongue rounded, one-half width of mouth opening, its posterior border free, slightly notched; vomerine teeth in two transverse round patches between choanae.

Forelimb strong and short; heavy glandular patch on upper surface of forearms. Adpressed forelimb with fourth finger crossing middle of body. First finger longer than second and fourth, reaching penultimate phalanx of third. Lateral fringes of fingers slightly developed; shovel-like tubercle on base of first finger; palmar tubercles rounded. Hind limb short, stout, tarsometatarsal articulation reaching axilla. Tibia equal to femur. Tibial glandular patches present. Toes slightly webbed; subarticular tubercles of toes soft, rounded. Inner metatarsal tubercle shovel-like, unpigmented, moderately 

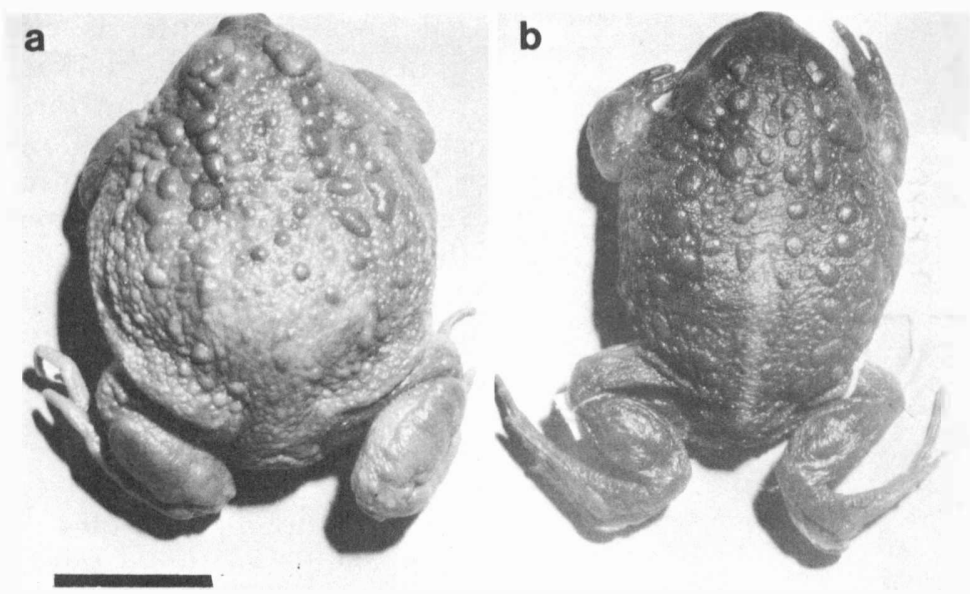

FIG. 2. A. Holotype of Odontophrynus barrioi from Famatina Mountains, La Rioja Province, Argentina. B. A male specimen of $O$. occidentalis from Malargue, Mendoza Province, Argentina. Bar equals $2 \mathrm{~cm}$.

developed and cornified; outer small, rounded. Tarsal ridge shovel-like, distinct. Heels touching with hind limbs bent at right angles to body.

Dorsal skin granular, with scattered, irregularly arranged, rounded glandular warts. Parotoid glands irregular, rounded. Venter heavily granular everywhere, more distinctly granular in coxal and anal regions. A transverse fold of skin across throat, denoting presence of vocal sac, almost unpigmented externally. A faint gray brownish nuptial pad on thumb.

Coloration in Life.-Brownish above; faint lateral and dorsal yellowish longitudinal bands recognizable; warts darker brown. Ventrally bluish or brownish, with scattered white granuli. No light vertebral stripe present. Coloration in alcohol. Dorsally gray yellowish; dorsal warts darker; ventrally whitish.

Measurements of the Holotype (in $\mathrm{mm}$ ).-Snout-vent 56; head length 18.5 ; head width 23.5; hind limb 63; forelimb 29; axilla-groin 25.5 .

Measurements of Paratypes (in $\mathrm{mm}$ ).Males: snout-vent 48-52.5; head length 16.5-18; head width 23-24; hind limb 56-57; forelimb 31-32; axilla-groin
24-25. Females: snout-vent 53.5-55; head length 18-18; head width 21-25; hind limb 52-59; forelimb 28.5-31; axilla-groin 28.5-29. Size range in juvenile specimens: $27-37$.

Distribution.-Known only from the type-locality (Fig. 1).

Etymology.-The species is named after the late Avelino Barrio, University of Buenos Aires, Argentina, who contributed much to the ecological knowledge of this anuran group.

Remarks. - Significant differences between the tadpoles of Famatina Odontophrynus and tadpoles of Odontophrynus occidentalis from Mendoza Province have been also observed (Cei and Crespo, in press). Tadpoles of Odontophrynus barrioi (stages 35-42, after Gossner, 1960) show stouter and darker bodies; snout bluntly rounded, less protruding than in occidentalis larvae; spiraculum opening dorsolaterally; different internasal distance; nostrils more laterally located; tip of tail gently rounded, almost acuminate in occidentalis; lower beak more heavily pigmented, with stronger denticulations; and less broadly interrupted second upper row of denticles.

Larval characteristics support the differences in morphology of adults. 

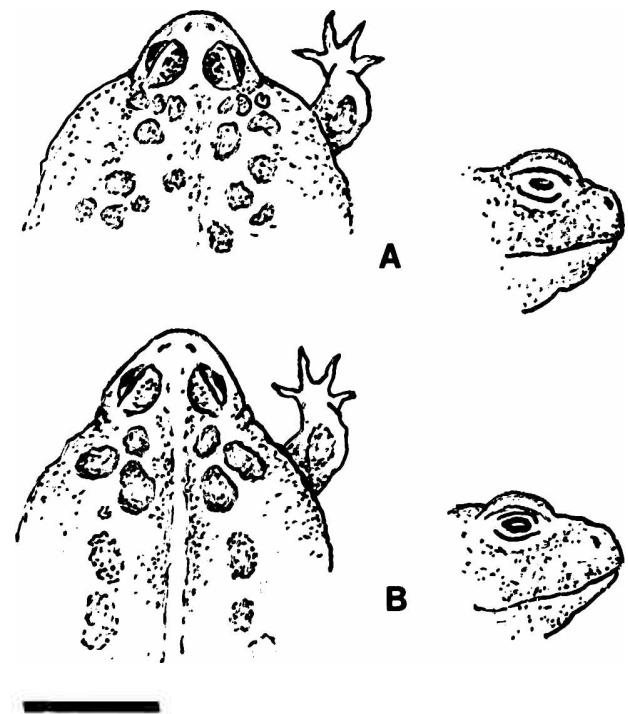

B

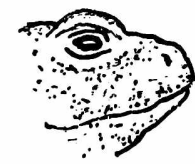

FIG. 3. Dorsal and lateral aspects of $O$. barrio (A) and O. occidentalis (B). Bar equals $2 \mathrm{~cm}$.

Odontophrynus barrioi at first sight appears larger and stouter than occidentalis, with a smaller and more truncate head and shorter forelimbs and hind limbs. In comparison with our description of O. barrioi, O. occidentalis (Berg, 1898) has the head length contained less than $3^{1 / 2}$ times in the body length; nostrils nearer to eye than to tip of snout; diameter of eye greater than its distance from nostril; interorbital distance equal to upper eyelid; fringes of fingers well developed; subarticular tubercles of toes strong, prominent; inner shovel-like metatarsal tubercle very strong, cornified, black-pigmented; tibia shorter than femur; adpressed forelimb with fourth finger crossing groin; tarsometatarsal articulation reaching between tympanum and eye; heels separated with hind limbs bent at right angles to body. Significant osteological differences are also present (Crespo and Cei, in press). Moreover, different skin structure and coloration may be recognized: the parotoid glands larger, symmetrical in O. cccidentalis (Fig. 3); enlarged glandular patches rather regularly arranged in dorsal longitudi- nal rows; the venter is more heavily granular yellowish, darker on lower hind limb surfaces. The dorsum is olive brown with indistinct yellowish shades; a light vertebral stripe. Throat of males intensely black; faint grayish nuptial thumb pads. A combination of 16 different morphological characters support specific divergence between $O$. occidentalis and $O$. barrioi.

Ecology and reproduction of this isolated species from the subarid environments of La Rioja "sierras" are practically unknown. Tadpoles in all stages of development were found from October to April in small pools of running water in their montane habitat. As in $O$. occidentalis, adults are fossorial and secretive, difficult to observe except in the mating periods.

Under the same environmental conditions the rate of growth of $O$. barrioi is apparently more accelerated than in O. occidentalis. Metamorphosed toads of both species were captured in October-November 1978 in the Famatina and Chacras de Coria (near the city of Mendoza), and were placed, at about the same time, under laboratory conditions in São Paulo. However, after nine months, significant differences between the two samples were found in size and development. On 1 August 1979 , the $O$. occidentalis sample ranged from 34 to $55 \mathrm{~mm}\left(\bar{x}_{1}=43.4\right)$; the $O$. barrioi sample from 50 to $60 \mathrm{~mm}\left(\bar{x}_{1}=57.0\right)$.

\section{DISCUSSION}

The population here described as $O$. barrioi has $2 n=22$ chromosomes (Ruiz et al., in press), as do other diploid species of the genus Odontophrynus, and a secondary constriction on the short arm of pair 11. Silver stain-banding patterns showing the active ribosomal gene sites in pair 11 are similar in all $O$. occidentalis populations. C-banding, however, is different in pairs 1 and 2 . $O$. barrioi has a block of constitutive heterochromatin on the pericentromeric area of the metacentric pair 1, mostly on the short arm. This feature does not 


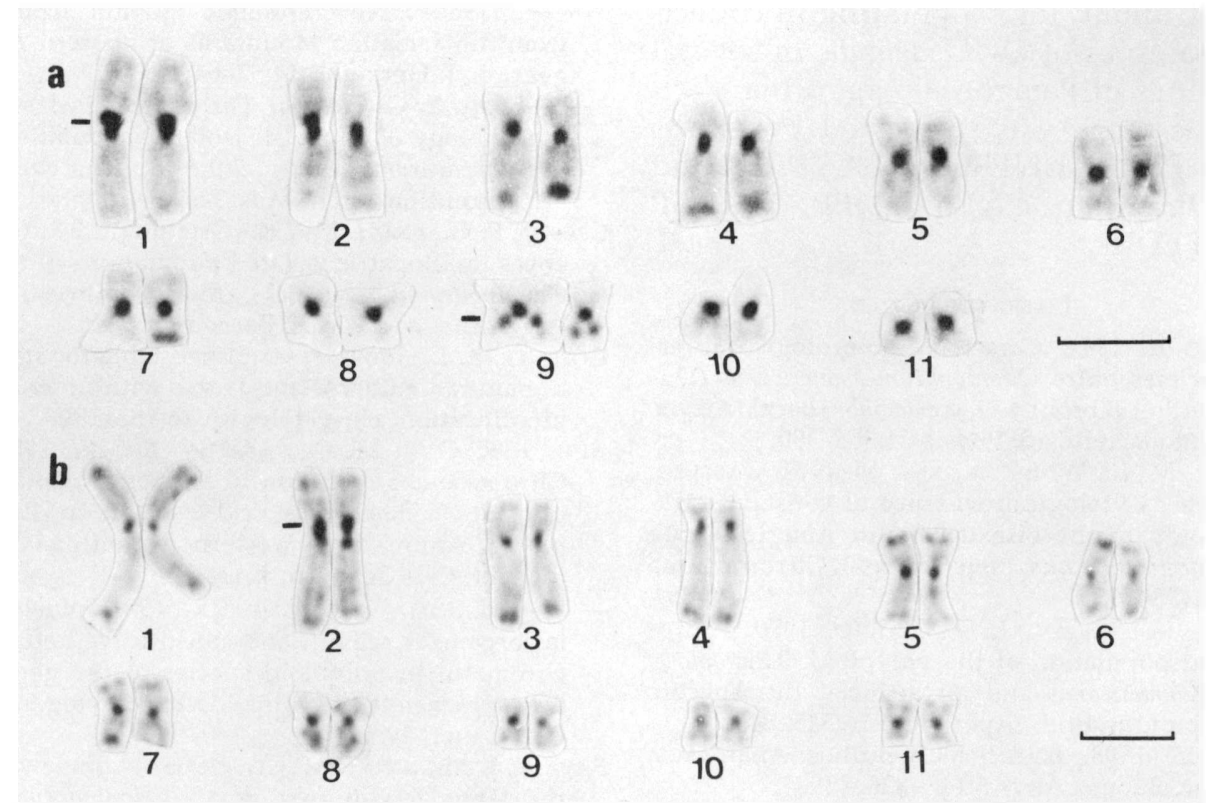

FIG. 4. C-banded karyotypes showing the main blocks of pericentromeric constitutive heterochromatin: on pair 1 in $O$. barrioi (a) and on pair 2 in $O$. occidentalis (b), as described in Ruiz et al. (in press). Bars equal $5 \mu \mathrm{m}$.

appear in $O$. occidentalis, which bears a heterochromatic block on the submetacentric pair 2 (Fig. 4).

The combination of unique morphological, karyotype, larval (Cei and Crespo, in press) and osteological (Crespo and Cei, in press) character states characterize $O$. barrioi as a separate entity of the $O$. occidentalis group. Since the new species, at about $2200 \mathrm{~m}$ of altitude, is geographically isolated from $O$. occidentalis, these differences may well result from selection. Reproductive isolation would also allow independent differentiation in the genetic pool. Chromosome modifications, including gene duplications, heterochromatic blocks and structural rearrangements would also reinforce the barriers which separate the diverging species.

Present endemic conditions prevailing in the herpetofaunal elements of Famatina Mountains may be correlated with the environmental changes in this geomorphologically isolated embossment following Pleistocene glaciation. Geographical speciation of the $\mathrm{O}$. occidentalis group probably fits the general adaptive process pointed out for some representative reptiles from that region (Cei, 1980b). O. barrioi may be added to the phyletic occidentalis line in the cladogram recently proposed by Ruiz et al. (1981) on the basis of nucleolar organizer regions and constitutive heterochromatin in the polyploid species complex of the genus Odontophrynus.

A significant relationship between karyotype and phenotype in both the isolated Famatina species and in the scattered southern $O$. occidentalis populations is probable. Further information is needed concerning karyological patterns throughout the range of these toads.

Acknowledgments. - Special thanks are due to Alejandro Scolaro from the Centro Nacional Patagonico, Puerto Mad- 
ryn, Chubut, for cooperating in collecting samples of $O$. occidentalis in several localities of Patagonia, Argentina.

This work was supported by grants from PNUD-UNESCO RLA 78/024 and the Brazilian CNPq/FINEP, FAPESP and FEDIB.

\section{LITERATURE CITED}

BARRIO, A. 1964. Caracteres eto-ecológicos diferenciales entre Odontophrynus americanus (Duméril et Bibron) y O. occidentalis (Berg) (Anura, Leptodactylidae). Physis 24:385-390.

BEÇAK, M. L., W. BEÇAK, AND M. N. I. RABELlo. 1966. Cytological evidence of constant tetraploidy in the bisexual South American frog Odontophrynus americanus. Chromosoma 19:188-193.

, AND L. D. VizorTo. 1970. A diploid population of the polyploid Odontophrynus americanus and an artificial intraspecific triploid hybrid. Experientia 26:545-546.

BERG, C. 1898. Batracios argentinos. Anal. Mus. Nac. Buenos Aires 5:147-226.

CEI, J. M. 1980a. Amphibians of Argentina. Monit. Zool. Ital. Monogr. 2:1-609. 1980b. New endemic iguanid lizards from the Famatina Mountains of western Argentina. J. Herpetol. 14:57-64.

, AND E. G. CRESPO. Differences in larval morphology of allopatric isolated populations of Odontophrynus occidentalis group from western Argentina. Arch. Mus. Bocage. In press.

CREsPo, E. G., AND J. M. CEl. Osteological differences in allopatric isolated populations of the Odontophrynus occidentalis group from western Argentina. Arch. Mus. Bocage. In press.

GOSSNER, K. L. 1960. A simplified table for staging anuran embryos and larvae with notes on identification. Herpetologica 16:183-190.

RuIz, I. R. G., J. M. CEI, AND W. BEÇAK. 1982. Chromosomal evolution in allopatric populations of Odontophrynus occidentalis group (Amphibia, Anura) from western Argentina. Cytogenet. Cell Genet. In press.

M. SOMA, AND W. BEÇAK. 1981. Nucleolar organizer regions and constitutive heterochromatin in polyploid species of the genus Odontophrynus (Amphibia, Anura). Cytogenet. Cell Genet. 29:84-98.

SAVAGE, J. M., AND J. M. CEI. 1965. A review of the leptodactylid frog genus Odontophrynus. Herpetologica 24:178-195.

Accepted: 24 Sept. 1981. 